\title{
Measuring Circularity in Food Supply Chain Using Life Cycle Assessment; Refining Oil from Olive Kernel
}

\author{
Amin Nikkhah ${ }^{1,2, *(\mathbb{D})}$, Saeed Firouzi ${ }^{3}$, Keyvan Dadaei $^{3}$ and Sam Van Haute ${ }^{1,2}$ \\ 1 Department of Food Technology, Safety and Health, Faculty of Bioscience Engineering, Ghent University, \\ Coupure Links 653, 9000 Ghent, Belgium; Sam.vanhaute@ghent.ac.kr \\ 2 Department of Environmental Technology, Food Technology and Molecular Biotechnology, Ghent University \\ Global Campus, Incheon 21985, Korea \\ 3 Department of Agronomy, College of Agriculture, Rasht Branch, Islamic Azad University, \\ Rasht 41476-54919, Iran; firoozi@iaurasht.ac.ir (S.F.); dadaee.keyvan@yahoo.com (K.D.) \\ * Correspondence: Amin.Nikkhah@ugent.be
}

Citation: Nikkhah, A.; Firouzi, S.; Dadaei, K.; Van Haute, S. Measuring Circularity in Food Supply Chain Using Life Cycle Assessment; Refining Oil from Olive Kernel. Foods 2021, 10, 590. https://doi.org/ $10.3390 /$ foods 10030590

Academic Editors: Cristina

Alamprese; Emma Chiavaro and Francesco Caponio

Received: 26 February 2021

Accepted: 8 March 2021

Published: 11 March 2021

Publisher's Note: MDPI stays neutral with regard to jurisdictional claims in published maps and institutional affiliations.

Copyright: (C) 2021 by the authors. Licensee MDPI, Basel, Switzerland. This article is an open access article distributed under the terms and conditions of the Creative Commons Attribution (CC BY) license (https:// creativecommons.org/licenses/by/ $4.0 /)$

\begin{abstract}
Valorization of food waste is a potential strategy toward a circular food supply chain. In this regard, measuring the circularity of food waste valorization systems is highly important to better understand multiple environmental impacts. Therefore, this study investigated the circularity of a food waste valorization system (refining oil from olive kernel) using a life cycle assessment methodology. An inventory of an industrial-based olive kernel oil production system is also provided in this study. The system boundary was the cradle to the factory gate of the production system. The results indicated that natural gas consumption was the highest contributor to most of the investigated impact categories. The global warming potential of one $\mathrm{kg}$ of oil produced from olive kernel was calculated to be $1.37 \mathrm{~kg} \mathrm{CO}_{2}$ eq. Moreover, the calculated damages of $1 \mathrm{~kg}$ oil production from olive kernel to human health, ecosystem quality, and resource depletion were $5.29 \times 10^{-7}$ DALY, $0.12 \mathrm{PDF} \cdot \mathrm{m}^{2} \cdot \mathrm{yr}$. , and $24.40 \mathrm{MJ}$, respectively.
\end{abstract}

Keywords: circular economy; environmental impact; global warming; valorization of waste

\section{Introduction}

The circular economy concept is gaining growing attention as an alternative to the linear economy - "take, make, waste,"-which exists now [1,2]. In a linear economy, natural resources are transformed into goods that provide economic value; however, they come with a limited life span, and are disposed of in the environment with minimum recovery of resources $[3,4]$. This system puts enormous stress on the carrying capacity of the planet [5]. The circular economy describes a system with minimum loss of resources by reusing, recycling, and recovering materials and energy [6-9]. Various strategies have been suggested for moving from a linear economy to a circular one, including R-based frameworks, such as the 3Rs strategy (reduce-reuse-recycle), the 4Rs (introducing "recover" as the fourth R), the 6Rs, and even the 9Rs [10,11].

The measurement of circularity is the first step in moving toward a circular system, as quoted by Peter Ducker: "what gets measured gets managed" [1]. There is not a unique approach for measuring a circular economy, since the understanding of a circular economy is still being explored [12]. To date, some assessment indices have been applied to measure circularity, such as the material circularity indicator [13], the circular economy index [14], material flow analysis [15], food loss and waste [16], and life cycle assessment (LCA) methodology [17,18]. Corona et al. (2019) [19] reviewed the applied approaches for measuring circularity and found three assessment frameworks, seven measurement indices, and nine assessment indicators. In this regard, LCA has been used for decades for the evaluation of the environmental impact of products and services but, more recently, it has shown to be a promising method to measure circularity. It is an appropriate method to 
investigate the environmental consequences of circular product designs and large-scale changes to move toward a more circular economy [8]. However, in recent years, LCA has been applied to measure circularity in various sectors, such as bio-based materials [20,21], tourism [5], and concrete production [22]. There are also some published documents addressing the connection between LCA and the circular economy concept in the food supply chain $[16,23,24]$.

In the case of the food supply chain, approximately one-third of the total global food production, which is equal to 1.3 billion tons per year, is wasted in the food production/consumption chain [25]. This includes food loss (such as losses and spoilage at the producer level before the market) or waste (such as losses at retailer and consumer levels) [26]. In fact, food loss and waste (FLW) refer to a certain amount of food, nutrients, or calories that intentionally/unintentionally disappear from food systems [27]. A large part of FLW is avoidable, and could be decreased by implementing different strategies at each level of the life cycle of the production system $[28,29]$. Although food waste has been understood as a critical global issue [30], food waste has high potential for reuse or recovery in a circular economy prospective [31].

In this regard, the olive-based products industry is an interesting case, as it is an economically important industry [32]. As a globally energy-intensive sector, the olive processing industry faces sustainability challenges [33]. Espadas-Aldana et al. (2019) [34] studied 23 published papers on the LCA of olives and olive oil and concluded that the global warming potential (GWP) of one liter of olive oil production is equal to $1.6 \mathrm{~kg}$ $\mathrm{CO}_{2}$ eq. The olive oil production supply chain also faces crucial challenges regarding waste management. For example, $80 \%$ of olive mass is composed of olive pulp and stones; therefore, waste production is four times higher than that produced within the extraction process [34]. In this regard, the by-products and residues generated in olive processing are not commonly used and end up as waste [33]. Thus, valorization of food waste could be considered as an effective strategy to make the supply chain of olive-based products more circular. In this regard, measuring the circularity of food waste valorization systems is highly important for improving understanding of multiple environmental impacts. One of these wastes is olive kernel (stone). Olive kernel is an important by-product generated in the pitted table olive industry [35]. The characterization and application of olive kernel are described in Figure 1. However, the current and main use of olive kernel is as direct solid feedstock for biofuel generation for domestic application [36]. However, this currently may not be a realistic option for an oil-rich country. In this regard, establishing an environmentally efficient approach for olive kernel utilization could actually improve the overall sustainability of olive-based product supply chains. This paper is the first report on the LCA of industrial-scale refining oil from olive kernel (as an olive processing waste valorization approach) system. 


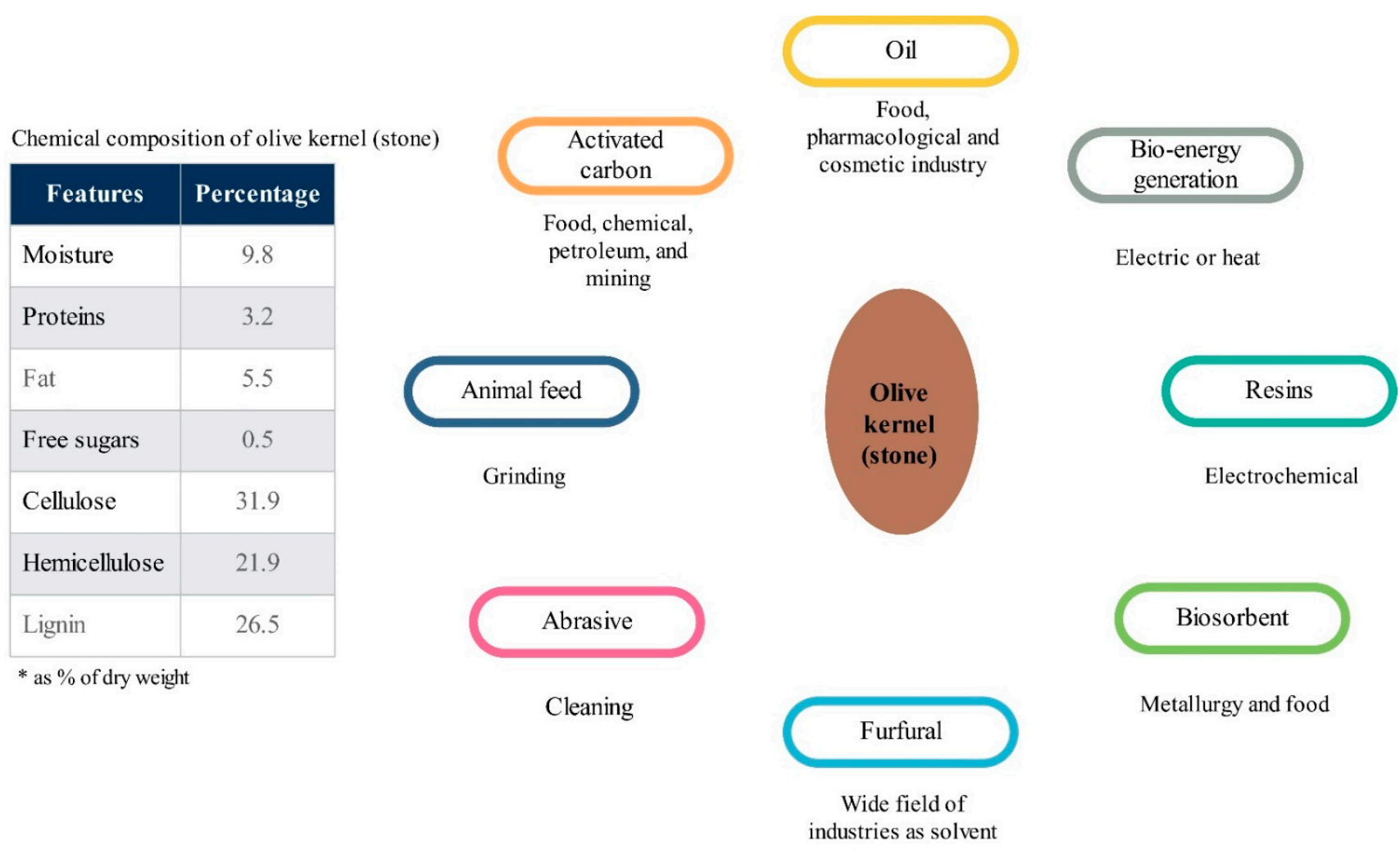

Figure 1. Characterization and application of olive kernel [37].

\section{Materials and Methods}

\subsection{Refining Oil from Olive Kernel}

The olive kernel oil production company investigated in this study is located in Iran. Olives (Olea europaea L.) were grown in Iran, and the uses of olive fruits in the studied region are: (i) raw material for extra virgin olive oil production, (ii) inside dishes (pitted table olive), and (iii) raw material for pickling. Solid-liquid olive pomace and olive mill wastewater are the two major by-products of the extra virgin olive oil production system [38]. The kernel must be separated from the olive fruit in the second and third abovementioned olive fruit applications. Therefore, olive kernel is a common source of waste in olive fruit processing systems (Figure 2). Olive kernel can be used to produce oil. The characterization of olive kernel oil was described by Moghaddam et al. (2012) [39].

The industrial olive kernel oil production process is shown in Figure 3. Olive kernels are transported to the processing plant, and the factory is located in the olive oil production/processing area. A small amount of olive pulp is stuck to kernels because it cannot be completely separated from the olive kernels in olive processing (Figure $2 \mathrm{~b}$ ). The received kernels are washed to remove impurities. Then, they are crushed to ease the release of the oil and are subsequently mixed. Afterward, the liquid (including oil and water) is separated through a decanter. In the next step, the oil is separated from the water and the olive kernel oil is extracted by a separator. Natural gas is consumed to heat the water in the boiler at a working temperature of 60 to $70{ }^{\circ} \mathrm{C}$. Its circulation in the decanter's double-walled jacket heats the dough (the crushed olive kernel, oil, and water). Mixer blades of the decanter provide a uniform spread of heat throughout the dough. Heating the dough contributes more efficiently to separating the three phases of oil, water, and pulp through centrifuging at 4000-4200 rpm. Moreover, the remaining pulp needs to be warmed to flow easily through the discharge mono pump of the decanter. Warm water is also added to the oil entering the separator in order to maximize the oil extraction rate. At the final step, a centrifuge rotating at a high rotational speed of 7000-7200 rpm separates the warm water and the olive kernel oil. 


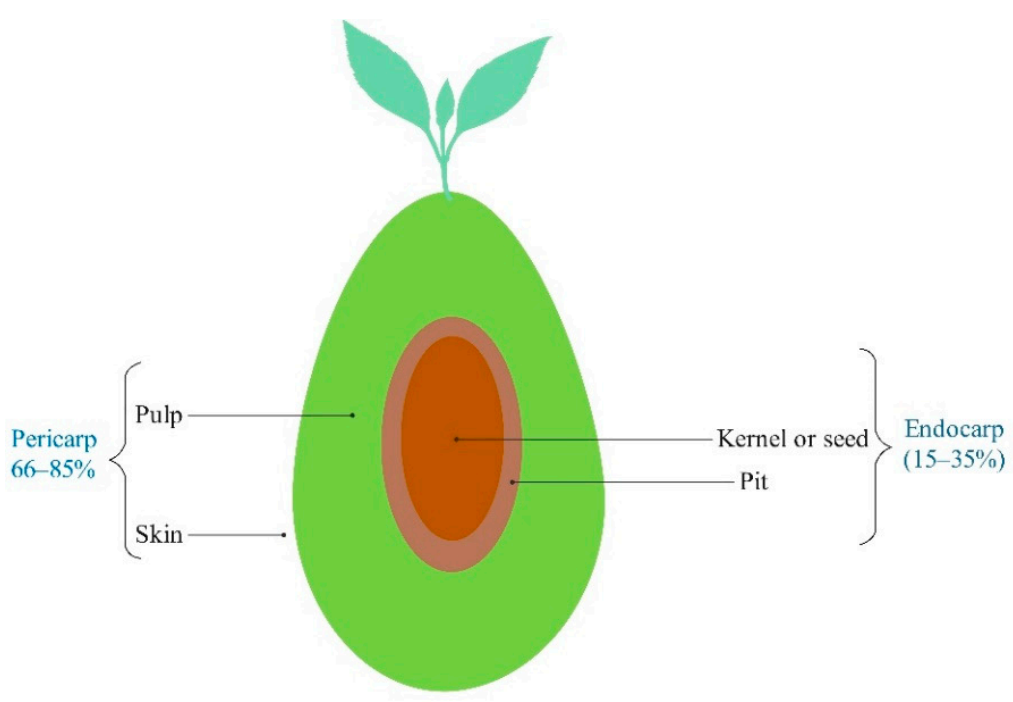

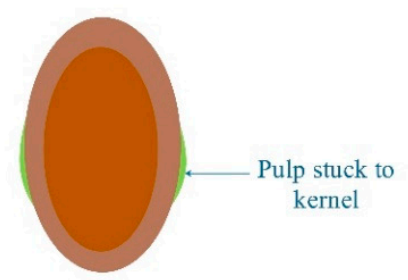

Figure 2. (a) different parts of an olive fruit $[40,41]$, (b) the parts of the olive which were used to produce oil in the case study. Note: In this study, the term "kernel" refers to "kernel, pit, and pulp stuck to kernel".

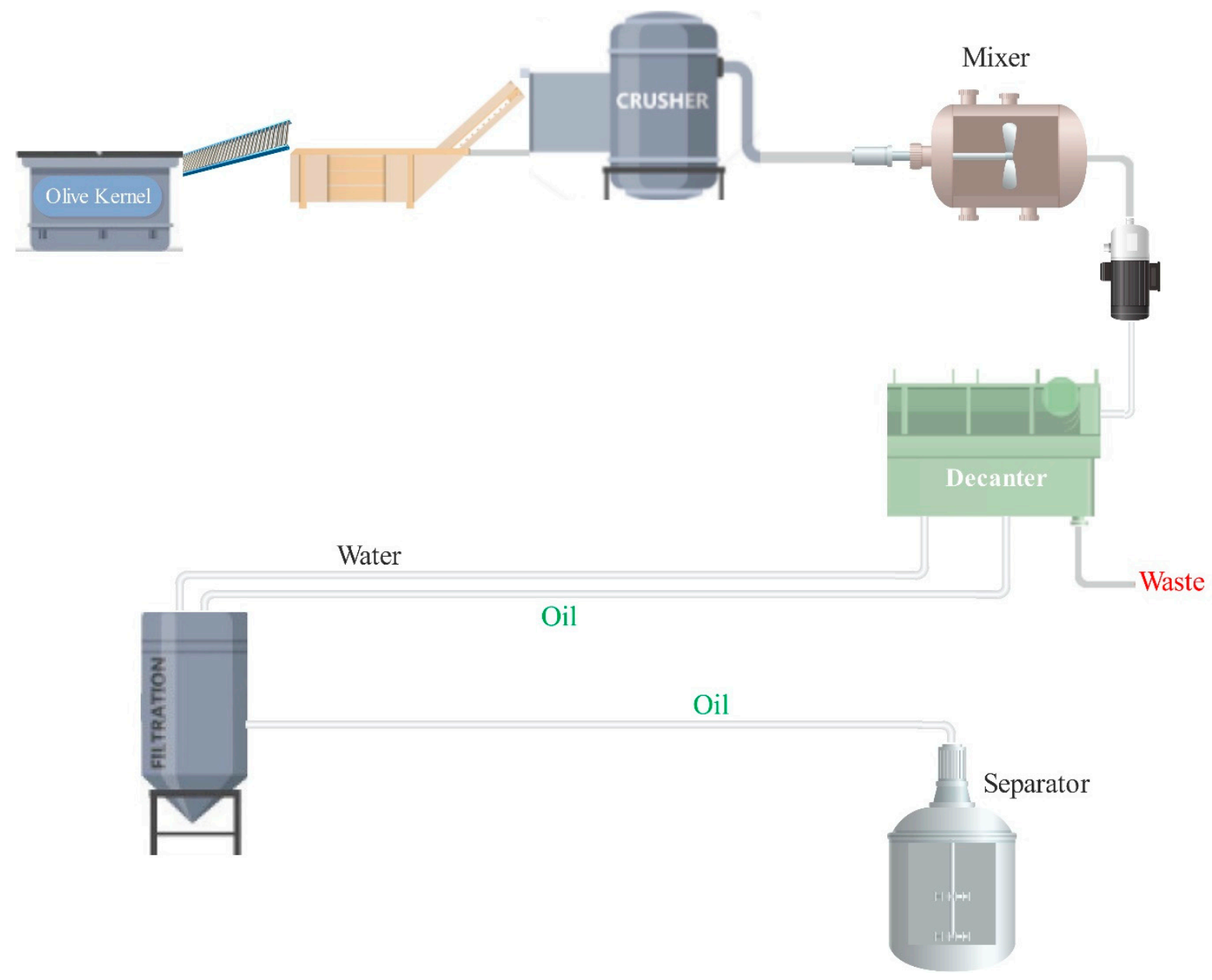

Figure 3. Olive oil production line with a daily production capacity of $100 \mathrm{~kg}$. 


\subsection{Measuring Circularity Using LCA}

In this study, LCA methodology was applied to measure the circularity of an olive waste valorization system. Based on the review by Espadas-Aldana et al. (2019) [34] on olive oil LCA studies, the functional units (FUs) are defined as the quantity of olive oil produced in $\mathrm{kg}$, and the energy content of the produced oil in MJ. Therefore, $1 \mathrm{~kg}$ of oil produced from olive kernel and $100 \mathrm{MJ}$ energy generation were selected as the FUs for this LCA analysis to compare the environmental consequences associated with oil production from olive kernel with other vegetable-based oil production systems. The heating value (energy equivalent) of olive kernel oil was considered to be the same as for olive oil at 34.5 MJ/L [42]. The system boundary of this LCA study was the cradle-to-factory gate olive kernel oil production.

The cradle-to-gate environmental impact for olive kernel oil production was evaluated using LCA. In this regard, the main primary inventory data for olive kernel production in the considered factory are shown in Table 1 . It should be noted that the input and output amounts were measured and recorded at the factory level, not through surveys or interviews. The experiments were performed in 2019. Experiments were conducted three times and the mean values are reported (Table 1). The olive kernel was not included as an input for the LCA analysis, and it was considered as a burden-free input; this is because it is a by-product/waste of a food production system. Therefore, the environmental impacts of wastewater from the olive kernel production system are not included in the system boundary. In other words, the assumption of not considering the wastewater treatment is due to the fact that olive kernel was not included as an input for the LCA analysis, as it is actually a by-product/waste of an olive processing system. Packaging is also excluded from the system boundary. The emitted pollutants were divided into off-site and on-site emissions. The emitted pollutants in the off-site phase (production of input materials) were adapted from the Ecoinvent 3.0 database using SimaPro 9.0.0.49 software. The datasets applied for calculation of emissions from off-site operations are shown in Appendix A, Table 1. The on-site emissions of natural gas consumption (see Appendix A, Table 2) were calculated and added to the on-site emission section using SimaPro software. The inventory of emissions for refining one kilogram oil from olive kernel is provided as Supplementary 1.

Table 1. Main primary inventory data for the olive kernel oil production system.

\begin{tabular}{llcc}
\hline Inputs and Outputs & Unit & Quantity & \\
\hline & & Per 1 kg Produced Oil & Per 100 MJ Produced Oil \\
\hline Inputs & $\mathrm{kg}$ & 47.72 & 150.83 \\
- Olive kernel & $\mathrm{m}^{3}$ & 0.05 & 0.14 \\
-Water consumption & $\mathrm{m}^{3}$ & 0.52 & 1.65 \\
-Natural gas & $\mathrm{kWh}$ & 0.10 & 0.31 \\
-Electricity & $\mathrm{h}$ & 0.16 & 0.50 \\
- Human labor & ton $\times \mathrm{km}$ & 0.34 & 1.07 \\
-Transportation of the produced oil & & & $100 \mathrm{MJ}$ \\
\hline Outputs & $\%$ & $1 \mathrm{~kg}$ & 2.09 \\
-Olive kernel oil & & 2.09 & \\
\hline
\end{tabular}

In the third step of the LCA study, IMPACT 2002+ was employed as the impact assessment (IA) methodology due to its hybrid application of IMPACT 2002, Eco-Indicator 99, CML, and IPCC, all of which cover various impact and damage categories. This impact assessment (IA) methodology evaluates the environmental impacts based on the $15 \mathrm{impact}$ categories, and also divides the impact categories into four damage categories: human health, ecosystem quality, GWP, and resource depletion. The human health damage category is represented as disability-adjusted life year (DALY), ecosystem quality as PDF. $\mathrm{m}^{2} \cdot \mathrm{yr}$., GWP as $\mathrm{kg} \mathrm{CO}_{2} \mathrm{eq}$, and resource depletion as MJ. The fourth and last step of conducting an 
LCA study is the interpretation of the LCA results, which are explained in the Results and Discussion section. The fourth step of an LCA study includes the determination of hotspots, the specification of areas with a potential for improvement, and recommendations [43]. A detailed explanation of this IA methodology can be found in Jolliet et al. (2003) [44]. A flowchart of the utilization of LCA for measuring the circularity of olive kernel oil production systems is demonstrated in Figure 4. Edraw Max (ver. 9.1, 2018; Sheung Wan, Hong Kong, China) software was used for the representation of graphical items.

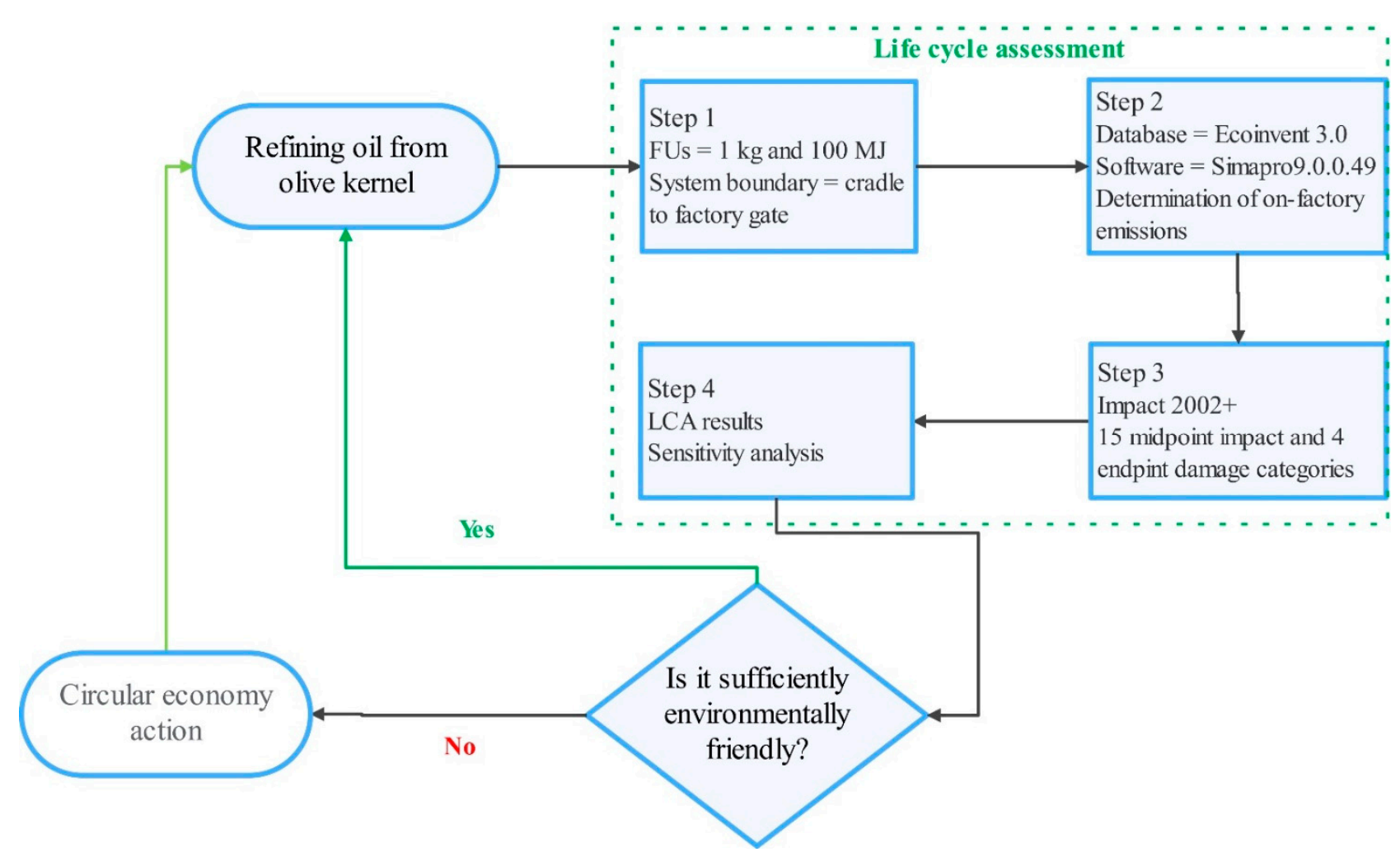

Figure 4. Measuring the circularity of olive kernel oil production using life cycle assessment (LCA) methodology.

There are several sources of uncertainty in an LCA study [45]. It is important to take into account the uncertainty of LCA results which can be due to a lack of accuracy in the collected data [46], the initial assumption [47], the allocation method [48], the selection of functional units [49], the determination of on-site emissions [50], and the type of IA methodology [51]. Therefore, to test the consistency of the LCA results obtained in this study, a quantitative uncertainty analysis was conducted to evaluate the effect of IA methodology selection on the final LCA results. In this regard, the GWP impact category was selected for comparison, as it is the mutual impact category among the investigated IA methodologies. The selected impact assessment methodologies were IMPACT 2002+, ReCiPe 2016 [52], CML-IA baseline [53], EDIP 2003 [54], EF [55], EN $15804+$ A2 [56], Environmental Prices [57], EPD [58] and ILCD [59]. The IA methodologies evaluated by this study are available on SimaPro 9.0.0.49-a widely used software for LCA analysis $[60,61]$.

One limitation of this research comes from the limited number (one industrial-scale company refining oil from olive kernel) of investigated olive kernel oil factories. Another limitation of this study is that, compared with studies on the LCA of extra virgin olive oils - the highest quality of olive oils - this olive kernel study does not consider the olive quality indices, as suggested by Salomone et al. (2015) [62]. 


\section{Results and Discussion}

\subsection{Interpretation of Mid-Point LCA Results}

The quantified amounts of the environmental impacts of olive kernel oil production, based on different impact categories, are presented in Table 2. The environmental impact of $1 \mathrm{~kg}$ of olive kernel oil production on GWP was calculated as $1.37 \mathrm{~kg} \mathrm{CO}_{2} \mathrm{eq}$. This value of the abovementioned impact category for $100 \mathrm{MJ}$ energy generation was $4.32 \mathrm{~kg}$ $\mathrm{CO}_{2}$ eq. The GWP of one liter of olive oil production is equal to $1.6 \mathrm{~kg} \mathrm{CO}$ eq, according to Espadas-Aldana et al. (2019) [34]. They also indicated that the agricultural phase is the most impactful phase in the olive oil supply chain, responsible for $0.46 \mathrm{~kg} \mathrm{CO} 2 \mathrm{eq} / \mathrm{kg}$ of GWP. In the case of refining oil from olive kernel, olives are not used in the system, and the by-product of the olive postharvest waste was used to produce oil. Then, the environmental impacts of the agricultural phase are not accounted for in this system. Therefore, the environmental impacts of oil production from olive kernel are low, making the conventional olive processing systems more circular through waste valorization (olive kernel) of the system. If it is assumed that the production of oil from kernels means less olive oil needs to be produced elsewhere for cosmetic and pharmacological purposes (Figure 1), then this process can save around $0.23 \mathrm{~kg} \mathrm{CO}_{2}$ per each $\mathrm{kg}$ of oil produced from olive kernel in the investigated system.

Table 2. Environmental consequence of the olive kernel oil production system based on different impact categories.

\begin{tabular}{|c|c|c|c|}
\hline \multirow[t]{2}{*}{ Impact Category } & \multirow[t]{2}{*}{ Unit } & \multicolumn{2}{|c|}{ Quantity } \\
\hline & & Per 1 kg Produced Oil & Per 100 MJ Produced Energy \\
\hline Global warming & $\mathrm{kgCO} 2 \mathrm{eq}$ & 1.37 & 4.32 \\
\hline Non-renewable energy & MJ primary & 26.40 & 83.44 \\
\hline Mineral extraction & MJ surplus & 0.005 & 0.02 \\
\hline Ozone layer depletion & kg CFC-11eq & $1.57 \times 10^{-7}$ & $4.97 \times 10^{-7}$ \\
\hline Non-carcinogens & $\mathrm{kg} \mathrm{C}_{2} \mathrm{H}_{3} \mathrm{Cl}$ eq & 0.02 & 0.05 \\
\hline Carcinogens & $\mathrm{kg} \mathrm{C}_{2} \mathrm{H}_{3} \mathrm{Cl}$ eq & 0.08 & 0.24 \\
\hline Ionizing radiation & Bq C-14 eq & 1.94 & 6.14 \\
\hline Respiratory organics & $\mathrm{kg} \mathrm{C}_{2} \mathrm{H}_{4}$ eq & $3.84 \times 10^{-4}$ & $1.39 \times 10^{-3}$ \\
\hline Respiratory inorganics & kg PM2.5eq & $4.40 \times 10^{-4}$ & $1.21 \times 10^{-3}$ \\
\hline Aquatic ecotoxicity & kg TEG water & 68.07 & 215.16 \\
\hline Terrestrial ecotoxicity & kg TEG soil & 12.71 & 40.16 \\
\hline Aquatic eutrophication & $\mathrm{kg} \mathrm{PO}_{4} \mathrm{P}$-lim & $3.28 \times 10^{-5}$ & $1.04 \times 10^{-4}$ \\
\hline Terrestrial acid/nutri & $\mathrm{kg} \mathrm{SO}_{2} \mathrm{eq}$ & 0.007 & 0.02 \\
\hline Land occupation & $\mathrm{m}^{2}$ org.arable & 0.009 & 0.03 \\
\hline Aquatic acidification & $\mathrm{kg} \mathrm{SO} \mathrm{eq}$ & 0.002 & 0.01 \\
\hline
\end{tabular}

Figure 5 demonstrates the proportion of inputs to the environmental effects of the olive kernel chain. Natural gas consumption was the highest contributor to the most investigated impact categories. The share of natural gas from off-farm emissions on GWP in olive kernel oil was $83 \%$. On-site emissions contributed to the impact categories of GWP, respiratory organics, respiratory inorganics, and terrestrial ecotoxicity; contributions of on-site emissions to these impact categories were $73,12,16$, and $2 \%$, respectively.

\subsection{Interpretation of End-Point Damage Assessment}

Figure 6 displays the damage assessment of the olive kernel oil chain. According to the results, the production of $1 \mathrm{~kg}$ of oil from olive kernel led to $5.29 \times 10^{-7}$ DALY damage to human health. The current study investigated the environmental impacts associated with the olive kernel oil production system, and the chemical and microbiological health risk of the final produced oil was not involved in the LCA analysis. Further research is required to examine the human health risk caused by the consumption of oil produced from olive kernel, as well as to gain a proper understanding of the sustainability of the olive kernel oil production system throughout its life cycle. The damages of $1 \mathrm{~kg}$ of oil 
production from olive kernel to ecosystem quality, GWP, and resource depletion were $1.21 \times 10^{-2} \mathrm{PDF} \cdot \mathrm{m}^{2} \cdot \mathrm{yr} ., 1.37 \mathrm{~kg} \mathrm{CO}{ }_{2} \mathrm{eq}$, and $24.40 \mathrm{MJ}$, respectively (Figure 6). The environmental indices of the investigated olive kernel oil production system based on different phases of the production system are shown in Table 3.

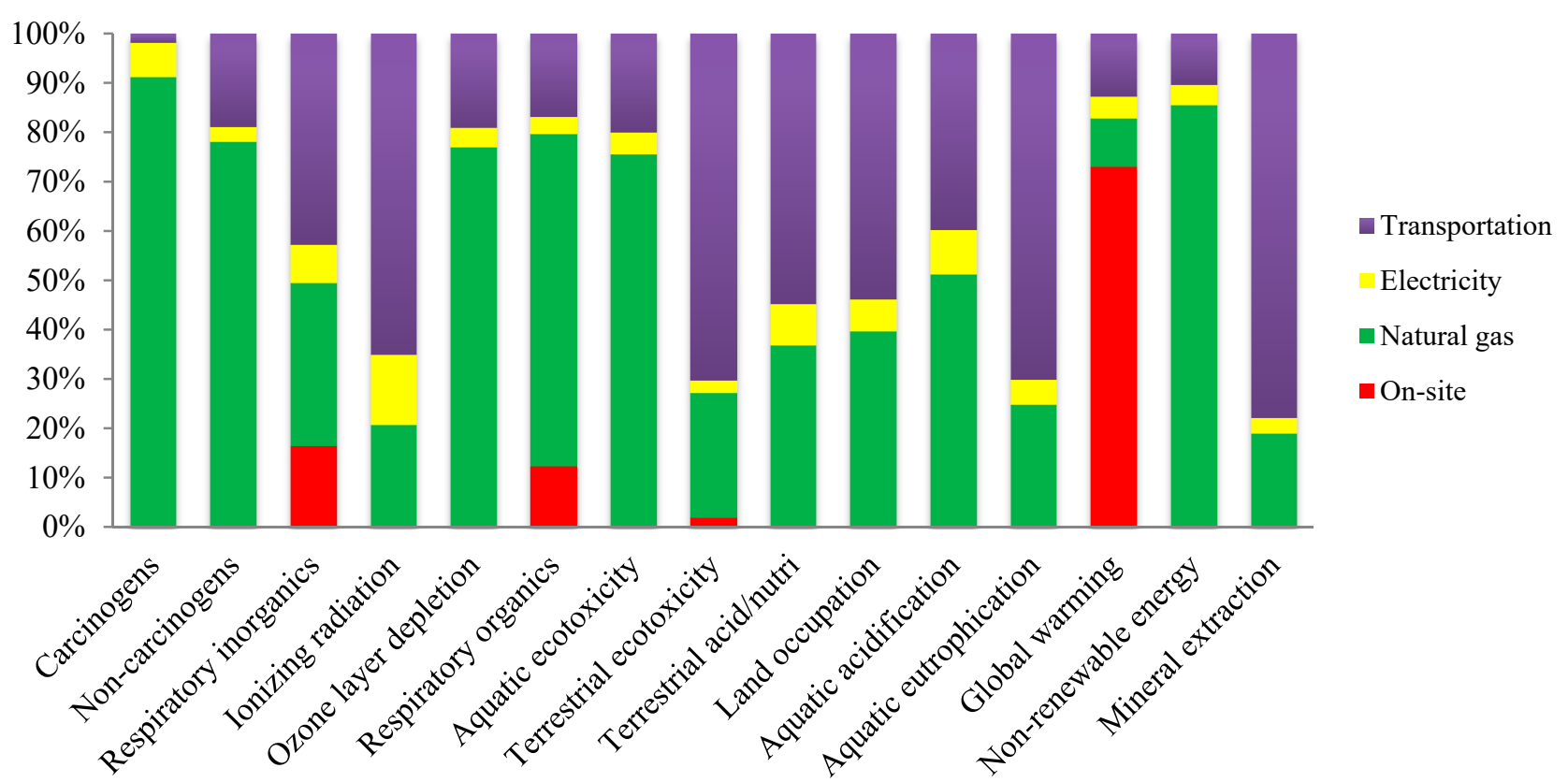

Figure 5. Contribution of consumed inputs to the environmental impact of the olive kernel oil production system.

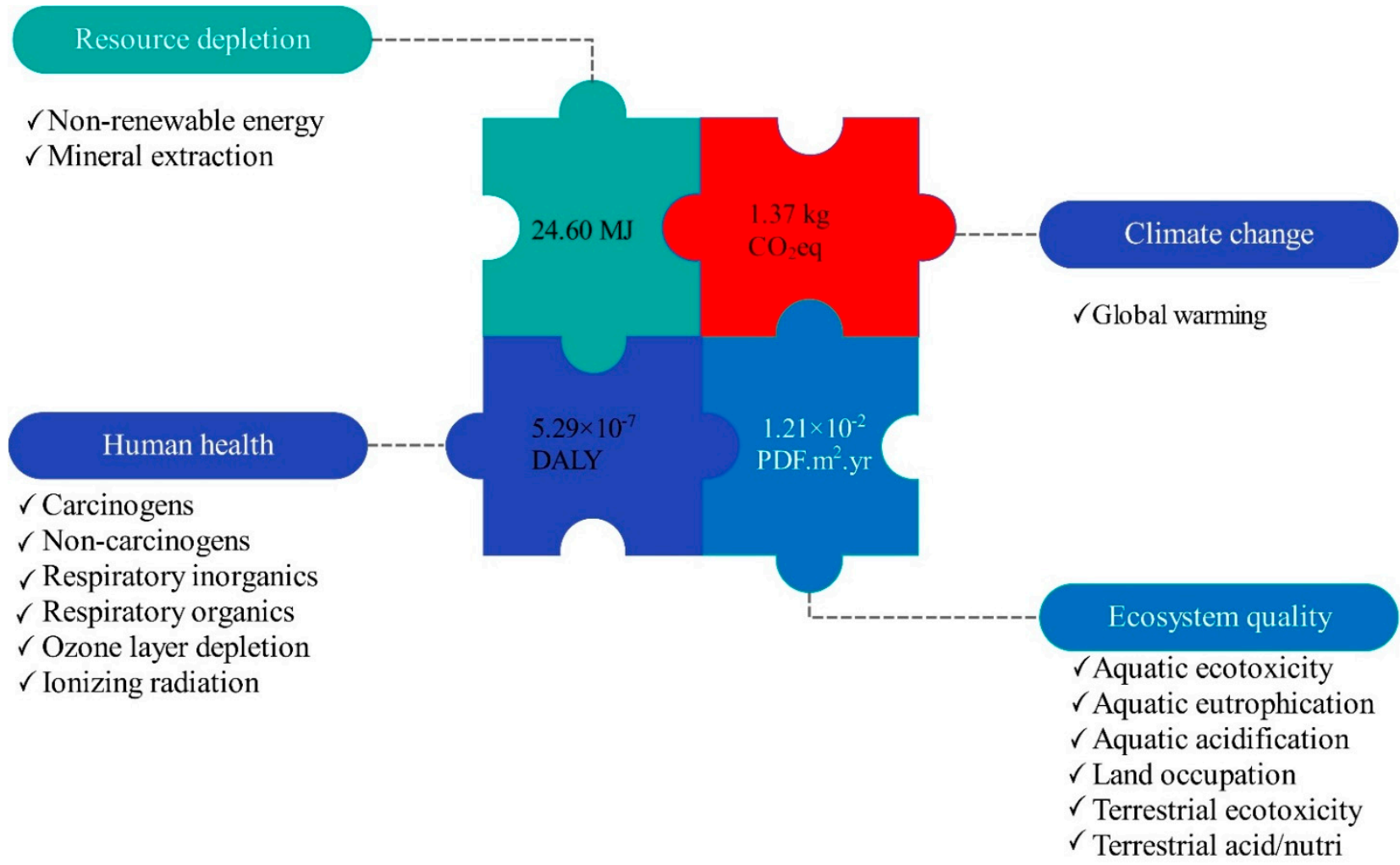

Figure 6. Damage assessment of olive kernel oil production (per $1 \mathrm{~kg}$ produced oil). 
Table 3. Environmental impacts of the olive kernel oil production system based on different damage categories.

\begin{tabular}{|c|c|c|c|c|c|c|c|c|c|c|c|c|}
\hline \multirow[b]{3}{*}{$\begin{array}{l}\text { Damage } \\
\text { Category }\end{array}$} & \multicolumn{9}{|c|}{ Off-Site } & \multirow{2}{*}{\multicolumn{3}{|c|}{$\begin{array}{c}\text { On-Site } \\
\text { On-Factory }\end{array}$}} \\
\hline & \multicolumn{3}{|c|}{ Electricity } & \multicolumn{3}{|c|}{ Natural Gas } & \multicolumn{3}{|c|}{ Transportation } & & & \\
\hline & Damage Assessment & Normalized & Weighted & Damage Assessment & Normalized & Weighted & Damage Assessment & Normalized & Weighted & Damage Assessment & Normalized & Weighted \\
\hline $\begin{array}{l}\text { Ecosystem } \\
\text { quality }\end{array}$ & $3.95 \times 10^{-3}$ PDF.m².yr & $2.8 \times 10^{-7}$ & 0.29 & $3.46 \times 10^{-2}$ PDF.m ${ }^{2} . \mathrm{yr}$ & $2.53 \times 10^{-6}$ & 2.53 & $8.08 \times 10^{-2}$ PDF.m ${ }^{2} \cdot y r$ & $5.89 \times 10^{-6}$ & 5.89 & $2.02 \times 10^{-3}$ PDF.m ${ }^{2} \cdot \mathrm{yr}$ & $1.47 \times 10^{-7}$ & 0.15 \\
\hline $\begin{array}{l}\text { Climate } \\
\text { change }\end{array}$ & $0.06 \mathrm{~kg} \mathrm{CO}_{2} \mathrm{eq}$ & $6.28 \times 10^{-6}$ & 6.28 & $0.13 \mathrm{~kg} \mathrm{CO}_{2} \mathrm{eq}$ & $1.35 \times 10^{-5}$ & 13.48 & $0.17 \mathrm{~kg} \mathrm{CO}_{2} \mathrm{eq}$ & $1.75 \times 10^{-5}$ & 17.52 & $1.00 \mathrm{~kg} \mathrm{CO}_{2} \mathrm{eq}$ & $1.01 \times 10^{-4}$ & 100.91 \\
\hline
\end{tabular}


The single scores of the damage categories in olive kernel oil are shown in Figure 7. The total weighted environmental damage from refining oil from olive kernel was calculated as $395 \mu \mathrm{Pt} / \mathrm{FU}$. Natural gas was the largest contributor to the total environmental impacts of the studied system, with a share of $80 \%$ (including its background and on-site emissions). As explained in the Materials and Methods section, natural gas is used in olive kernel processing to heat water in order to (a) facilitate the separation of water and oil from pulp in the decanter, (b) contribute to the flow of the remaining pulp in the decanter, and (c) separate water from olive kernel oil in the separator. A preliminary experiment shows that the optimum dough temperature to extract purer oil is around $35^{\circ} \mathrm{C}$, which is associated with the circulating water temperature at around $60-70{ }^{\circ} \mathrm{C}$ in the studied system. Moreover, a temperature of around $35^{\circ} \mathrm{C}$ for the water added to the separator might be efficient. Nevertheless, further research is needed to determine the optimum water temperature to avoid extra natural gas/heat consumption.

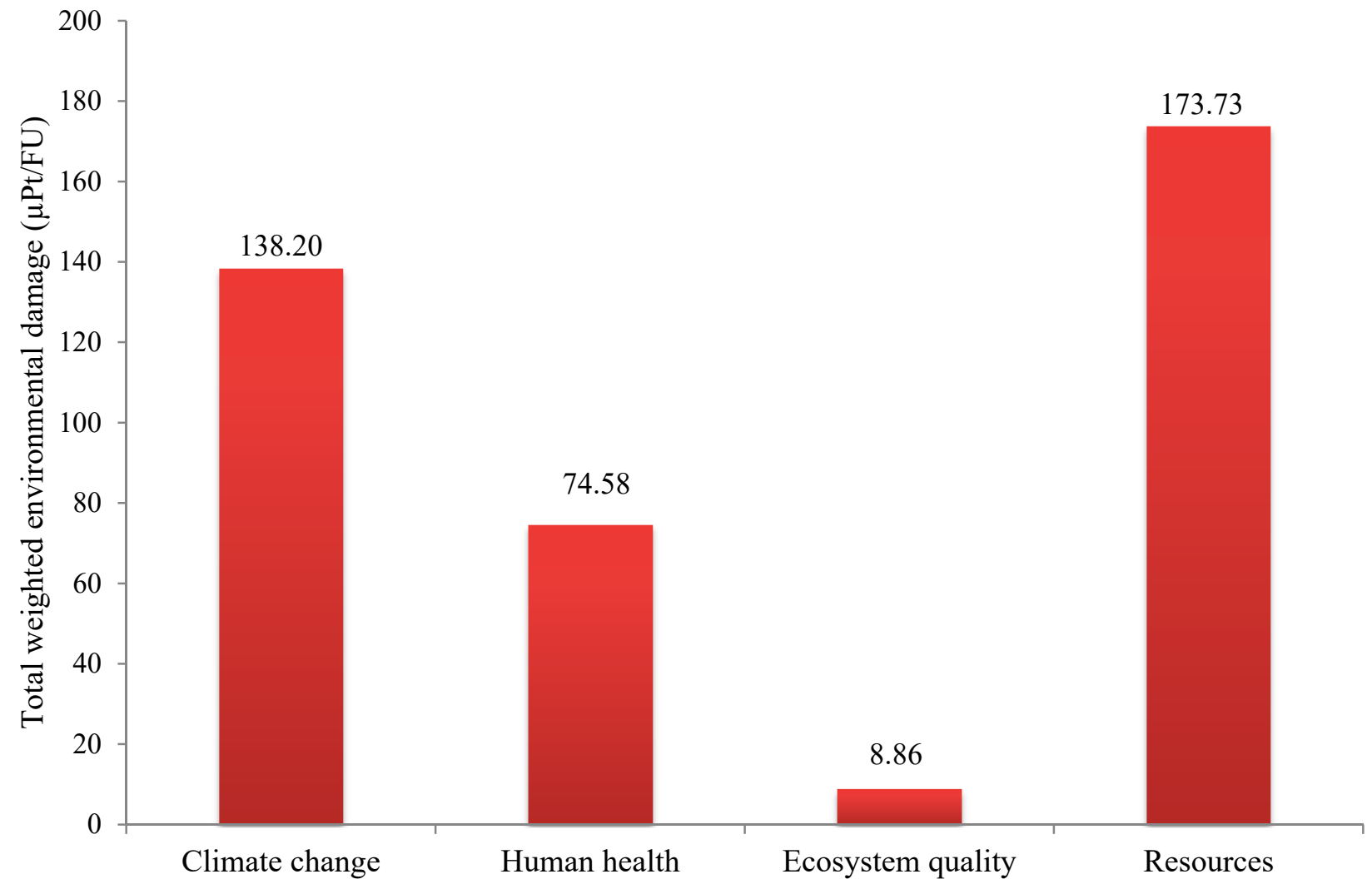

Figure 7. Single scores of damage categories in the olive kernel oil production chain (unit $=\mu \mathrm{Pt}$ ).

Khounani et al. (2021) [33] showed that the total environmental burdens of olive oil systems can be reduced by $12 \%$ by applying agro-biorefinery strategies based on olive cultivation and the extraction of fruit and pomace oil. There are also other ways to valorize olive processing wastes, such as energy generation. One LCA study highlighted significant greenhouse gas emission savings through olive husk (the solid portion remaining after pressing olives) application in a mobile pyrolysis process [63]. In another LCA study, Intini et al. (2012) [64] reported the environmental advantages of using de-oiled pomace and waste wood as feedstock for biofuel production, in terms of greenhouse gas emissions reduction. Multiple environmental measures could be applied in order to improve the sustainability of olive processing. In this regard, Martinez-Hernandez et al. (2014) [65] indicated how integrated process schemes can be used to develop a sustainable Jatrophabased biorefinery system. 


\subsection{Uncertainty of GWP's Results}

A unique IA methodology for LCA analysis in food systems does not exist. Different IA methodologies may apply for characterization, and the selection of IA methodology can therefore affect the final LCA results. The characterization index of GWP for refining oil from olive kernel, based on the application of various IA methodologies, is illustrated in Figure 8 . These results may correspond with the findings of relevant LCA studies on the same topic. The results revealed that the GWP of the production of $1 \mathrm{~kg}$ of olive kernel oil ranges from 1.37 to $1.47 \mathrm{kgCO}_{2}$ eq. The lowest estimation of GWP belonged to IMPACT $2002+$, and the highest to the EDPI and EF methodologies. The results are in agreement with the reports by Fathollahi et al. (2018) [47] and Paramesh et al. (2018) [51], which indicated that selection of IA methodology can slightly affect LCA results in some impact categories in the food system. Therefore, it is recommended to consider the impact of IA selection as a source of uncertainty in future research concerning LCA in the food supply chain.

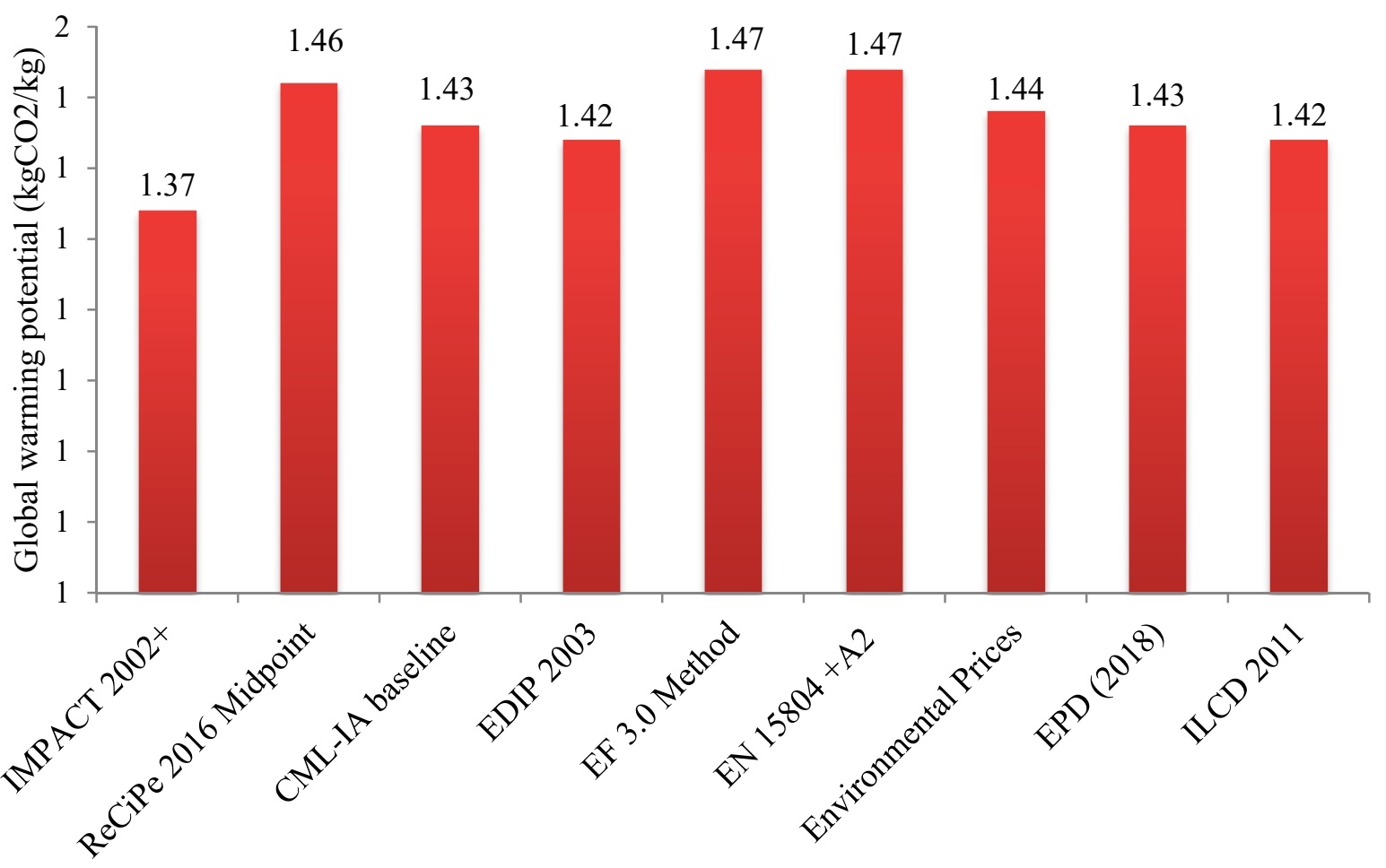

Figure 8. Effect of impact assessment methodology selection on the global warming potential (GWP) results.

\section{Conclusions}

This study applied LCA to measure the circularity of a food waste system-in this case, refining oil from olive kernel. The damages of $1 \mathrm{~kg}$ of oil production from olive kernel to GWP, human health, ecosystem quality, and resource depletion were $1.37 \mathrm{~kg} \mathrm{CO}_{2} \mathrm{eq}$, $5.29 \times 10^{-7} \mathrm{DALY}, 1.21 \times 10^{-2} \mathrm{PDF} \cdot \mathrm{m}^{2} \cdot \mathrm{yr}$., and $24.40 \mathrm{MJ}$, respectively. The results highlighted that the studied system is relatively circular, resulting in low environmental impacts. Olive processing systems could be made more circular through food waste valorization. By managing the consumption of energy sources, such as natural gas, olive kernel oil production systems can become environmentally efficient. In this regard, further research is needed to determine the optimum temperature of olive kernel dough in the decanter, as well as the optimum temperature for warm water when added to the separator in the process of oil extraction from olive kernel. Further research is also required to explore the human health and microbiological risks of the oil produced from olive kernels, which were not considered in this study. 
Supplementary Materials: The following are available online at https:/ / www.mdpi.com/2304-815 8/10/3/590/s1, Supplementary 1 .

Author Contributions: A.N. developed the initial concept of the research and contributed to the analysis and writing of the first draft of the manuscript. S.F. contributed to data collection and manuscript writing and editing. K.D. contributed to data collection and technical support. S.V.H. contributed to the concept, supervision, and editing of the article. All authors have read and agreed to the published version of the manuscript.

Funding: This research was funded by the Ghent University Global Campus.

Institutional Review Board Statement: Not applicable.

Informed Consent Statement: Not applicable.

Data Availability Statement: The inventory of the industrial-based olive kernel oil production system is provided in the paper. In addition, the inventory of emissions for refining one kilogram oil from olive kernel is also provided as Supplementary 1.

Acknowledgments: The authors would like to acknowledge the support provided by the Ghent University Global Campus.

Conflicts of Interest: The authors declare that they have no conflicts of interest.

\section{Appendix A}

Table 1. Datasets applied for calculation of emissions from off-site operations.

\begin{tabular}{ccccc}
\hline Activity & Database & Category & Unit & Activity Uuid/Source \\
\hline Electricity & Ecoinvent 3 & IR & kWh & 668baf12-38db-47b7-8517-c0a18aa122f4 \\
Natural gas & Ecoinvent 3 & GLO & $\mathrm{M}^{3}$ & $65 f 221 \mathrm{cf}-\mathrm{b} 821-4 \mathrm{da} 1-\mathrm{a} 2 \mathrm{ed}-\mathrm{a} 67994 \mathrm{~b} 10 \mathrm{f} 42$ \\
Transport & Ecoinvent 3 & GLO & t.km & 413c356e-677d-4676-b816-0c0b20768d7a_03bf1369-1eec- \\
Water-Unspecified origins & Input from nature & IR & $\mathrm{M}^{3}$ & 49d0-bc4b-8b29efa826b9.spold \\
\hline
\end{tabular}

Table 2. Coefficients for calculation of emissions from natural gas combustion (gram).

\begin{tabular}{ccc}
\hline Emission & Coefficients [66,67] & Quantity (per on kg Produced Olive Kernel Oil) \\
\hline Carbon dioxide $\left(\mathrm{CO}_{2}\right)$ & 38.70 & 996.14 \\
Methane $\left(\mathrm{CH}_{4}\right)$ & $7.40 \times 10^{-4}$ & $1.90 \times 10^{-2}$ \\
Dinitrogen monoxide $\left(\mathrm{N}_{2} \mathrm{O}\right)$ & $7.11 \times 10^{-4}$ & $1.83 \times 10^{-2}$ \\
Sulfur dioxide $\left(\mathrm{SO}_{2}\right)$ & $1.93 \times 10^{-4}$ & $4.97 \times 10^{-3}$ \\
Nickel (Ni) & $6.78 \times 10^{-7}$ & $1.75 \times 10^{-5}$ \\
Lead & $1.61 \times 10^{-7}$ & $4.14 \times 10^{-6}$ \\
Zinc (Zn) & $9.37 \times 10^{-6}$ & $2.41 \times 10^{-4}$ \\
Benzo(a)pyrene & $3.87 \times 10^{-9}$ & $9.96 \times 10^{-8}$ \\
Selenium (Se) & $7.75 \times 10^{-9}$ & $1.99 \times 10^{-7}$ \\
Organic compound & $3.50 \times 10^{-3}$ & $9.01 \times 10^{-2}$ \\
Volatile organic compound (VOC) & $1.70 \times 10^{-3}$ & $4.38 \times 10^{-2}$ \\
Particulates $(<2.5 \mu \mathrm{m})$ & $2.45 \times 10^{-3}$ & $6.31 \times 10^{-2}$ \\
\hline
\end{tabular}

\section{References}

1. Haupt, M.; Hellweg, S. Measuring the environmental sustainability of a circular economy. Environ. Sustain. Indic. $2019,1,100005$. [CrossRef]

2. Secondi, L. A Regression-Adjustment Approach with Control-Function for Estimating Economic Benefits of Targeted Circular Economy Practices: Evidence from European SMEs. Stud. Appl. Econ. 2020, 39. [CrossRef]

3. Ruggieri, A.; Braccini, A.M.; Poponi, S.; Mosconi, E.M. A meta-model of inter-organisational cooperation for the transition to a circular economy. Sustainability 2016, 8, 1153. [CrossRef]

4. Babbitt, C.W.; Gaustad, G.; Fisher, A.; Chen, W.Q.; Liu, G. Closing the loop on circular economy research: From theory to practice and back again. Resour. Conserv. Recycl. 2018, 135, 1-2. [CrossRef] 
5. Scheepens, A.E.; Vogtländer, J.G.; Brezet, J.C. Two life cycle assessment (LCA) based methods to analyse and design complex (regional) circular economy systems. Case: Making water tourism more sustainable. J. Clean. Prod. 2016, 114, 257-268. [CrossRef]

6. Ellen MacArthur Foundation. Towards the Circular Economy: Economic and Business Rationale for Accelerated Transition; Ellen MacArthur Foundation: Cowes, UK, 2013.

7. European Environment Agency. Signals: Well-Being and the Environment-Building a Resource-Efficient and Circular Economy in Europe Luxembourg; Publications Office of the European Union: Copenhagen, Denmark, 2014.

8. Haupt, M.; Zschokke, M. How can LCA support the circular economy?-63rd discussion forum on life cycle assessment, Zurich, Switzerland, November 30, 2016. Int. J. Life Cycle Assess. 2017, 22, 832-837. [CrossRef]

9. Patwa, N.; Sivarajah, U.; Seetharaman, A.; Sarkar, S.; Maiti, K.; Hingorani, K. Towards a circular economy: An emerging economies context. J. Bus. Res. 2021, 122, 725-735. [CrossRef]

10. Kirchherr, J.; Reike, D.; Hekkert, M. Conceptualizing the circular economy: An analysis of 114 definitions. Resour. Conserv. Recycl. 2017, 127, 221-232. [CrossRef]

11. Bassi, F.; Dias, J.G. The use of circular economy practices in SMEs across the EU. Resour. Conserv. Recycl. 2019, 146, 523-533. [CrossRef]

12. Korhonen, J.; Honkasalo, A.; Seppälä, J. Circular economy: The concept and its limitations. Ecol. Econ. 2018, 143, 37-46. [CrossRef]

13. Ellen MacArthur Foundation; Granta Design. An Approach Tomeasuring Circularity—Methodology; Ellen MacArthur Foundation: Cowes, UK, 2015.

14. Di Maio, F.; Rem, P.C. A robust indicator for promoting circular economy through recycling. J. Environ. Protect. 2015, 6, 1095. [CrossRef]

15. Linder, M.; Sarasini, S.; van Loon, P. A metric for quantifying product-level circularity. J. Ind. Ecol. 2017, 21, 545-558. [CrossRef]

16. Vilariño, M.V.; Franco, C.; Quarrington, C. Food loss and waste reduction as an integral part of a circular economy. Front. Environ. Sci. 2017, 5, 21. [CrossRef]

17. ISO (International Organization for Standardization). Environmental Management: Life Cycle Assessmente; Principles and Framework; British Standards Institution: London, UK, 2006; Volume 14040.

18. ISO (International Organization for Standardization). Environmental Management: Life Cycle Assessment; Requirements and Guidelines; International Standard Organisation: Geneva, Switzerland, 2006.

19. Corona, B.; Shen, L.; Reike, D.; Carreón, J.R.; Worrell, E. Towards sustainable development through the circular economy-A review and critical assessment on current circularity metrics. Resour. Conserv. Recycl. 2019, 151, 104498. [CrossRef]

20. Lokesh, K.; Matharu, A.S.; Kookos, I.K.; Ladakis, D.; Koutinas, A.; Morone, P.; Clark, J. Hybridised sustainability metrics for use in life cycle assessment of bio-based products: Resource efficiency and circularity. Green Chem. 2020, 22, 803-813. [CrossRef]

21. Dahiya, S.; Katakojwala, R.; Ramakrishna, S.; Mohan, S.V. Biobased Products and Life Cycle Assessment in the Context of Circular Economy and Sustainability. Mater. Circ. Econ. 2020, 2, 1-28. [CrossRef]

22. Colangelo, F.; Navarro, T.G.; Farina, I.; Petrillo, A. Comparative LCA of concrete with recycled aggregates: A circular economy mindset in Europe. Int. J. Life Cycle Assess. 2020, 25, 1790-1804. [CrossRef]

23. Pauer, E.; Wohner, B.; Heinrich, V.; Tacker, M. Assessing the environmental sustainability of food packaging: An extended life cycle assessment including packaging-related food losses and waste and circularity assessment. Sustainability 2019, 11, 925. [CrossRef]

24. Sadhukhan, J.; Dugmore, T.I.; Matharu, A.; Martinez-Hernandez, E.; Aburto, J.; Rahman, P.K.; Lynch, J. Perspectives on "game changer" global challenges for sustainable 21st century: Plant-based diet, unavoidable food waste biorefining, and circular economy. Sustainability 2020, 12, 1976. [CrossRef]

25. Dahiya, S.; Kumar, A.N.; Sravan, J.S.; Chatterjee, S.; Sarkar, O.; Mohan, S.V. Food waste biorefinery: Sustainable strategy for circular bioeconomy. Bioresour. Technol. 2018, 248, 2-12. [CrossRef] [PubMed]

26. Shafiee-Jood, M.; Cai, X. Reducing food loss and waste to enhance food security and environmental sustainability. Environ. Sci. Technol. 2016, 50, 8432-8443. [CrossRef] [PubMed]

27. Wesana, J.; Gellynck, X.; Dora, M.K.; Pearce, D.; De Steur, H. Measuring Food Losses in the Supply Chain through Value Stream Mapping: A Case Study in the Dairy Sector. In Saving Food; Academic Press: New York, NY, USA, 2019; pp. $249-277$.

28. Strotmann, C.; Göbel, C.; Friedrich, S.; Kreyenschmidt, J.; Ritter, G.; Teitscheid, P. A participatory approach to minimizing food waste in the food industry-A manual for managers. Sustainability 2017, 9, 66. [CrossRef]

29. Principato, L.; Ruini, L.; Guidi, M.; Secondi, L. Adopting the circular economy approach on food loss and waste: The case of Italian pasta production. Resour. Conserv. Recycl. 2019, 144, 82-89. [CrossRef]

30. Muhammad, N.I.S.; Rosentrater, K.A. Comparison of global-warming potential impact of food waste fermentation to landfill disposal. SN Appl. Sci. 2020, 2, 261. [CrossRef]

31. Ingrao, C.; Faccilongo, N.; Di Gioia, L.; Messineo, A. Food waste recovery into energy in a circular economy perspective: A comprehensive review of aspects related to plant operation and environmental assessment. J. Clean. Prod. 2018, 184, 869-892. [CrossRef]

32. Negro, M.J.; Manzanares, P.; Ruiz, E.; Castro, E.; Ballesteros, M. The biorefinery concept for the industrial valorization of residues from olive oil industry. In Olive Mill Waste; Academic Press: New York, NY, USA, 2017; pp. 57-78. 
33. Khounani, Z.; Hosseinzadeh-Bandbafha, H.; Moustakas, K.; Talebi, A.F.; Goli, S.A.H.; Rajaeifar, M.A.; Khoshnevisan, B.; Jouzani, G.S.; Peng, W.; Kim, K.H.; et al. Environmental life cycle assessment of different biorefinery platforms valorizing olive wastes to biofuel, phosphate salts, natural antioxidant, and an oxygenated fuel additive (triacetin). J. Clean. Prod. 2021, 278, 123916. [CrossRef]

34. Espadas-Aldana, G.; Vialle, C.; Belaud, J.P.; Vaca-Garcia, C.; Sablayrolles, C. Analysis and trends for Life Cycle Assessment of olive oil production. Sustain. Prod. Consum. 2019, 19, 216-230. [CrossRef]

35. Nunes, M.A.; Pimentel, F.B.; Costa, A.S.; Alves, R.C.; Oliveira, M.B.P. Olive by-products for functional and food applications: Challenging opportunities to face environmental constraints. Innov. Food Sci. Emerg. Technol. 2016, 35, 139-148. [CrossRef]

36. Gomez-Martin, A.; Chacartegui, R.; Ramirez-Rico, J.; Martinez-Fernandez, J. Performance improvement in olive stone's combustion from a previous carbonization transformation. Fuel 2018, 228, 254-262. [CrossRef]

37. Rodríguez, G.; Lama, A.; Rodríguez, R.; Jiménez, A.; Guillén, R.; Fernández-Bolanos, J. Olive stone an attractive source of bioactive and valuable compounds. Bioresour. Technol. 2008, 99, 5261-5269. [CrossRef] [PubMed]

38. Batuecas, E.; Tommasi, T.; Battista, F.; Negro, V.; Sonetti, G.; Viotti, P.; Fino, D.; Mancini, G. Life Cycle Assessment of waste disposal from olive oil production: Anaerobic digestion and conventional disposal on soil. J. Environ. Manag. 2019, 237, 94-102. [CrossRef] [PubMed]

39. Moghaddam, G.; Vander Heyden, Y.; Rabiei, Z.; Sadeghi, N.; Oveisi, M.R.; Jannat, B.; Araghi, V.; Hassani, S.; Behzad, M.; Hajimahmoodi, M. Characterization of different olive pulp and kernel oils. J. Food Compos. Anal. 2012, 28, 54-60. [CrossRef]

40. Martins, F.P.; Kiritsakis, A. Olives and Olive Oil as Functional Foods: Bioactivity, Chemistry and Processing, 1st ed.; Kiritsakis, A., Shahidi, F., Eds.; Wiley: Hoboken, NJ, USA, 2017; pp. 81-105.

41. Kiritsakis, A.; Turkan, K.M.; Kiritsakis, K. Bailey's Industrial Oil and Fat Products, 7th ed.; Shahidi, F., Ed.; Wiley: Hoboken, NJ, USA, 2020. [CrossRef]

42. Cappelletti, G.M.; Ioppolo, G.; Nicoletti, G.M.; Russo, C. Energy requirement of extra virgin olive oil production. Sustainability 2014, 6, 4966-4974. [CrossRef]

43. Sundaram, S.; Siew, K.; Martinez-Hernandez, E. Biorefineries and chemical processes: Design, integration and sustainability analysis. Green Process. Synth. 2015, 4, 65-66. [CrossRef]

44. Jolliet, O.; Margni, M.; Charles, R.; Humbert, S.; Payet, J.; Rebitzer, G.; Rosenbaum, R. IMPACT 2002+: A new life cycle impact assessment methodology. Int. J. Life Cycle Assess. 2003, 8, 324. [CrossRef]

45. Zargar-Ershadi, S.Z.; Heidari, M.D.; Dutta, B.; Dias, G.; Pelletier, N. Comparative life cycle assessment of technologies and strategies to improve nitrogen use efficiency in egg supply chains. Resour. Conserv. Recycl. 2021, 166, 105275. [CrossRef]

46. Vásquez-Ibarra, L.; Rebolledo-Leiva, R.; Angulo-Meza, L.; González-Araya, M.C.; Iriarte, A. The joint use of life cycle assessment and data envelopment analysis methodologies for eco-efficiency assessment: A critical review, taxonomy and future research. Sci. Total Environ. 2020, 139538. [CrossRef]

47. Fathollahi, H.; Mousavi-Avval, S.H.; Akram, A.; Rafiee, S. Comparative energy, economic and environmental analyses of forage production systems for dairy farming. J. Clean. Prod. 2018, 182, 852-862. [CrossRef]

48. Cherubini, E.; Franco, D.; Zanghelini, G.M.; Soares, S.R. Uncertainty in LCA case study due to allocation approaches and life cycle impact assessment methods. Int. J. Life Cycle Assess. 2018, 23, 2055-2070. [CrossRef]

49. Noya, I.; González-García, S.; Bacenetti, J.; Fiala, M.; Moreira, M.T. Environmental impacts of the cultivation-phase associated with agricultural crops for feed production. J. Clean. Prod. 2018, 172, 3721-3733. [CrossRef]

50. Rezaei, M.; Soheilifard, F.; Keshvari, A. Impact of agrochemical emission models on the environmental assessment of paddy rice production using life cycle assessment approach. Energy Sources 2021, 1-16. [CrossRef]

51. Paramesh, V.; Arunachalam, V.; Nikkhah, A.; Das, B.; Ghnimi, S. Optimization of energy consumption and environmental impacts of arecanut production through coupled data envelopment analysis and life cycle assessment. J. Clean. Prod. 2018, 203, 674-684. [CrossRef]

52. Dekker, E.; Zijp, M.C.; van de Kamp, M.E.; Temme, E.H.; van Zelm, R. A taste of the new ReCiPe for life cycle assessment: Consequences of the updated impact assessment method on food product LCAs. Int. J. Life Cycle Assess. 2019, 1-10. [CrossRef]

53. Guinée, J.B.; Lindeijer, E. Handbook on Life Cycle Assessment-Operational Guide to the ISO Standards. In Handbook on Life Cycle Assessment: Operational Guide to the ISO Standards Series: Eco-Efficiency in Industry and Science; Guinée, J.B., Ed.; Springer: Dordrecht, The Netherlands, 2002.

54. Hauschild, M.Z.; Wenzel, H. Environmental Assessment of Products, Volume 2: Scientific Background; Springer: New York, NY, USA, 1998.

55. Huijbregts, M.A.; Hellweg, S.; Frischknecht, R.; Hungerbühler, K.; Hendriks, A.J. Ecological footprint accounting in the life cycle assessment of products. Ecol. Econ. 2008, 64, 798-807. [CrossRef]

56. EN 15804, BS EN 15804:2012. Standards Publication Sustainability of Construction Works-Environmental Product Declarations-Core Rules for the Product Category of Construction Products; European Committee for Standardization: Brussels, Belgium, 2014 ; Volume 70.

57. De Bruyn, S.; Ahdour, S.; Bijleveld, M.; De Graaff, L.; Schep, E.; Schroten, A.; Vergeer, R. Environmental Prices Handbook 2017-Methods and Numbers for Valuation of Environmental Impacts. 2018. Available online: https://www.cedelft.eu/en/ publications/2113/envionmental-prices-handbook-2017 (accessed on 12 January 2021).

58. PRE. SimaPro Database Manual Methods Library. 2019. Available online: https:// simapro.com/ (accessed on 28 January 2021). 
59. Chomkhamsri, K.; Wolf, M.A.; Pant, R. International reference life cycle data system (ILCD) handbook: Review schemes for life cycle assessment. Towards Life Cycle Sustain. Manag. 2011, 107-117. [CrossRef]

60. Herrmann, I.T.; Moltesen, A. Does it matter which Life Cycle Assessment (LCA) tool you choose?-A comparative assessment of SimaPro and GaBi. J. Clean. Prod. 2015, 86, 163-169. [CrossRef]

61. Hiloidhari, M.; Banerjee, R.; Rao, A.B. Life cycle assessment of sugar and electricity production under different sugarcane cultivation and cogeneration scenarios in India. J. Clean. Prod. 2020, 290, 125170. [CrossRef]

62. Salomone, R.; Cappelletti, G.M.; Malandrino, O.; Mistretta, M.; Neri, E.; Nicoletti, G.M.; Notarnicola, B.; Pattara, C.; Russo, C.; Saija, G. Life Cycle Assessment in the Olive Oil Sector. In Life Cycle Assessment in the Agri-food Sector; Springer: Cham, Switzerland, 2015; pp. 57-121.

63. El Hanandeh, A. Carbon abatement via treating the solid waste from the Australian olive industry in mobile pyrolysis units: LCA with uncertainty analysis. Waste Manag. Res. 2013, 31, 341-352. [CrossRef]

64. Intini, F.; Kuhtz, S.; Rospi, G. Life cycle assessment (LCA) of an energy recovery plant in the olive oil industries. Int. J. Energy Environ. 2012, 3, 541-552.

65. Martinez-Hernandez, E.; Martinez-Herrera, J.; Campbell, G.M.; Sadhukhan, J. Process integration, energy and GHG emission analyses of Jatropha-based biorefinery systems. Biomass Convers. Biorefinery 2014, 4, 105-124. [CrossRef]

66. EPA-Environmental Protection Agency Emission Factor Documentation for AP-42 Section 1.4-Natural Gas Combustion, Technical Support Division, Office of Air Quality Planning and Standards, Research Triangle Park, NC, USA, 1998. Available online: http:/ / www3.epa.gov/ttnchie1/ap42/ch01/bgdocs/b01s04.pdf (accessed on 8 January 2021).

67. Farahani, S.S.; Soheilifard, F.; Raini, M.G.N.; Kokei, D. Comparison of different tomato puree production phases from an environmental point of view. Int. J. Life Cycle Assess. 2019, 24, 1817-1827. [CrossRef] 